\title{
The Other Travelers: American Jihadists Beyond Syria and Iraq
}

Seamus Hughes, Emily Blackburn, and Andrew Mines

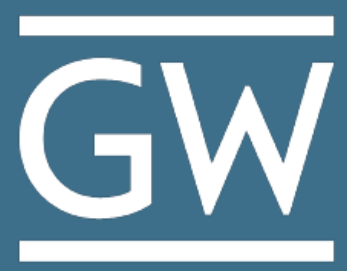

Program on Extremism 


\section{About the Program on Extremism}

The Program on Extremism at George Washington University provides analysis on issues related to violent and non-violent extremism. The Program spearheads innovative and thoughtful academic inquiry, producing empirical work that strengthens extremism research as a distinct field of study. The Program aims to develop pragmatic policy solutions that resonate with policymakers, civic leaders, and the general public.

\section{Acknowledgements}

This report was made possible by the hard work of the Program on Extremism's research team. The authors wish to thank the Program's Director Dr. Lorenzo Vidino, in addition to senior research fellow Devorah Margolin and research fellows Jon Lewis and Bennett Clifford for their tireless efforts to assist in the report's findings. The authors also wish to thank former senior research fellow Audrey Alexander for reviewing the report at multiple stages during the writing process. The Program's research assistants, including Amy Sinnenberg, Eric Ross, Caroline Zenkel, and Lee Ratson were instrumental in compiling data, editing, and confirming the final product.

The views expressed in this publication are solely those of the authors, and not necessarily those of the George Washington University. 


\section{Table of Contents}

Executive Summary $\quad 3$

Background $\quad 4$

$\begin{array}{ll}\text { Methodology } & 5\end{array}$

$\begin{array}{lr}\text { Preliminary Findings and Analysis } & 6\end{array}$

$\begin{array}{ll}\text { Conclusion } & 12\end{array}$

$\begin{array}{ll}\text { References } & \mathbf{1 3}\end{array}$

Appendix 1: List of Travelers $\quad 16$

Appendix 2: An Abridged History of Prior American Travelers Beyond Syria and Iraq 17 


\section{Executive Summary}

The mobilization of American foreign fighters to Islamic State-held territory in Syria and Iraq garnered extensive policy and media attention over the last several years. Following the decline of the Islamic State's territorial holdings, attention shifted to the remaining foreign fighters who either attempted to return to their home countries or were detained in Syria and Iraq.

Little focus has been paid, however, to the Americans who traveled-and continue to travel-to hotspots beyond Syria and Iraq. As the threat posed by jihadist groups overseas adjusts to new geopolitical dynamics, taking stock of these travelers in alternate theaters helps makes sense of the next possible phases of foreign fighter mobilization. This report examines cases of Americans who traveled or attempted to travel to jihadist conflict theaters outside of Syria and Iraq between January 2011 and July 2019, specifically Afghanistan-Pakistan (Af-Pak), Libya, Mali, Nigeria, the Sinai Peninsula, Somalia, and Yemen.

The report finds that:

- Despite the Islamic State's and alQaeda's calls for foreign jihadists to travel to join a multitude of local affiliates, the majority of American jihadist travelers gravitated to just three hotspots outside Syria and Iraq

- American jihadist travelers continued to join the same alternate theaters in the years leading up to, during, and after the loss of territory by the Islamic State in Iraq and Syria.

- While the Islamic State has eclipsed al-Qaeda in the number of American jihadist travelers it attracts, it remains to be seen if that reputational sway will continue to hold.

Foreign fighter flows are notoriously difficult to track. Given the sensitive nature of this type of research, it is likely that many American jihadist travelers will never be publicly identified. However, through open source research-including court records, media reports, interviews with law enforcement officials, and Freedom of Information Act requests - the authors identified 36 who attempted or successfully traveled overseas to join jihadist groups outside of Syria and Iraq. Because the number of travelers and attempted travelers is relatively small, it is difficult to make sweeping statements about this category of American foreign fighters. Nonetheless, of those 36 individuals:

- Ten successfully traveled to their intended destinations and 26 attempted to travel.

- The majority (74\%) attempted to travel to three jihadist hotspots: the Af-Pak region, Somalia, and Yemen.

- While al-Qaeda and its affiliates drew 79\% of known American travelers before the rise of the Islamic State, after 2014 the Islamic State and its affiliates drew $73 \%$ of all known American travelers.

- Travelers who succeeded in reaching their target destinations received significantly longer sentences (273 months on average) than those who were unsuccessful (186 months on average).

- The average age was 23.5 years-old and the vast majority were men, with only one woman identified. 


\section{Background}

Since 2011, tens of thousands of individuals from over 120 countries traveled to join militant groups in Syria and Iraq, at least 7,000 of whom are believed to have originated from Western countries. ${ }^{i}$ Following the declaration of an Islamic caliphate in June 2014, the majority of these recruits joined the Islamic State (IS). ${ }^{i i}$ In the American context, the Federal Bureau of Investigation (FBI) estimates that as many as 300 Americans have either traveled or attempted to travel to Syria or Iraq during this period to join militant groups. Within this group, the Program on Extremism was able to publicly identify 82 Americans who successfully traveled to Syria or Iraq. ${ }^{\text {iii }}$

In the wake of IS' territorial losses in Syria and Iraq starting as early as 2015, the numbers of foreign fighters traveling to the region tapered off. ${ }^{\text {iv }}$ Between 2015 and 2016, the Islamic State lost key territories along the Turkish-Syrian border that were vital for foreign fighter intake and processing. Subsequently, the group lost control of Raqqa and Mosul, its major strongholds in Syria and Iraq, respectively. In addition, IS began to declare a number of affiliate "provinces" in several global conflict hotspots, including Yemen, the Afghanistan-Pakistan (Af-Pak) region, Libya, and Somalia, among others. As a result, IS “core” territory in Syria and Iraq was only one of several theaters that jihadist foreign fighters from the United States attempted to join. With the decline of Syria and Iraq as the preeminent destinations for jihadist travelers, other hotspots like Libya and Af-Pak began to receive an increasing number of foreign jihadist travelers.

The post-2011 conflicts in Syria and Iraq drew one of the largest mobilizations of jihadist foreign fighters in history in terms of both scale and scope. However, an exclusive focus on the theaters of Syria and Iraq precludes insights into jihadist foreign fighter mobilizations to other battlefields. Moreover, the Islamic State is not the only organization that attracted jihadist travelers; during the same time period, alQaeda (AQ) and its affiliates continued to garner a steady stream of American and other Western recruits. To help remedy these deficits, this report seeks to highlight American jihadist travelers who sought out alternate conflict theaters beyond Syria and Iraq.

This report uses the term "American jihadist travelers" to refer to individuals with a nexus to the U.S. who traveled overseas to participate in jihadist groups. ${ }^{v}$ The term "travelers," as opposed to "foreign fighters," assumes that not all individuals who travel abroad to join insurgencies choose to fight. Rather, some of these individuals assume logistical, recruitment, and/or familial roles within these organizations. For example, in many cases women do not fight, but participate within jihadist groups in noncombat roles.vi As such, this definition is more inclusive of the multivalent roles played by foreign jihadist affiliates. 


\section{Methodology}

For this report, the authors compiled a dataset encompassing all known cases of U.S. individuals charged, arrested, or convicted for attempting or successfully traveling abroad to join jihadist organizations (excluding the region of Syria and Iraq) between January 2011 and July 2019. This project continues the work carried out by the Program on Extremism over the last few years examining American jihadists. vii

The Program's datasets draw on thousands of pages of federal court filings, FOIA requests and in-person interviews with U.S. prosecutors, national security officials, and returned travelers and their families. In total, this research found 36 American jihadists who successfully traveled or attempted to travel to Af-Pak, the Sinai Peninsula, Libya, Mali, Nigeria, Somalia, and Yemen. viii

To analyze each case, the authors relied on available media reports supplemented by primary source material. Using these primary and secondary sources, the authors coded for the following eight variables: age, gender, legal status, time of arrest, the year of attempted or successful travel, intended destination, success rate, and group affiliation. Data collection was largely limited to publicly available information. In some cases, reliable sources for some individual information could not be found.

The sample includes U.S. citizens, legal permanent residents, and other individuals with substantial ties to the U.S. The term "American" is used throughout this report to refer to these individuals.

The authors also made determinations for those who successfully traveled ( $\mathrm{n}=$ ten) and those who attempted to travel $(n=26)$ abroad. Those who left the United States and arrived at their intended destination qualify as having successfully traveled abroad. Individuals classified as having unsuccessfully traveled abroad made substantial progress in their efforts to travel, but failed to reach their intended destination either because they were prevented from leaving the United States or did not complete their journey.

Jihadist group associations were determined based on evidence in the individuals' associated court documents. Declared pledges of allegiance, conversations with FBI undercover employees and confidential human sources, and other indicators in these documents provided a holistic picture needed to determine group affiliation. Information was unavailable on group affiliations in only one instance, and the authors recorded two individuals who did not declare an affiliation prior to their travel attempts.

While the dataset is composed almost entirely of men, this likely does not reflect an accurate representation of all individuals who traveled to join jihadist organizations during the time period. As has been noted, women were more likely to remain undetected and avoided apprehension efforts when looking at jihadist travelers to Syria and Iraq. .

This study also accounts for individuals who traveled or attempted to travel multiple times. The reasons some individuals were able to travel or attempt to travel more than once vary from case to case. ${ }^{\mathrm{x}}$ For a variety of reasons, three individuals in the dataset made multiple attempts to travel. Each of the three cases includes two separate travel attempts, bringing the overall total of travel attempts within the dataset to 39 . 


\section{Preliminary Findings and Analysis}

Before, during, and after the Syrian civil war, travelers to alternate theaters mostly traveled to Afghanistan, Yemen, and Somalia (74\%). The Islamic State made only limited headway in drawing American recruits to its affiliates in its newly-declared provinces (Nigeria, Libya, and the Sinai Peninsula). The small number of known travel attempts shows that IS' local affiliates are on the radar for only a select minority of potential American recruits.

It is reasonable to expect Americans to continue to travel to these three theatersAf-Pak, Yemen, and Somalia-in proportionally higher numbers after the collapse of the caliphate in Syria and Iraq. There are a number of reasons. First, jihadist groups continue to launch persistent operations in these areas. Second, jihadist propaganda portrays these areas as vital historical battlefields of resistance against Western powers, and there are long legacies of foreign jihadist travel to these regions. Finally, traveling to these areas is relatively easy for Americans and there are more established routes for would-be foreign fighters. Despite organizational declarations about alternate destinationsparticularly for the Islamic State in the wake of territorial losses-the impact on the flow of American travelers appears to have been only minor.

Because the sample size is relatively small, it is difficult to make sweeping statements about motivational drivers for this category of American foreign fighters. In some cases, individuals' demographic backgrounds or countries of origin appear to have played a significant role in their decision-making process. After increased international monitoring mechanisms and closing borders shut down possibilities of traveling to Syria and Iraq, the prospect of assisting jihadist groups elsewhere also had significant impact for several individuals. Some travelers learned about possible alternate travel destinations either through online research, communications with supporters or recruiters, or propaganda produced by affiliate groups. 


\section{Comparison of Alternate Theaters and Syria/Iraq (2011-2019)}

Prior to 2013, most American foreign fighters attempted to travel to conflict theaters outside of Syria and Iraq (69\%). Between 2013 and 2017, however, the vast majority of attempts to join jihadist groups in conflict theaters were to Syria and Iraq
(91\%). During the last two years, there were no known attempts by Americans to travel to Syria and Iraq. However, there were seven attempts to travel to alternate theaters.

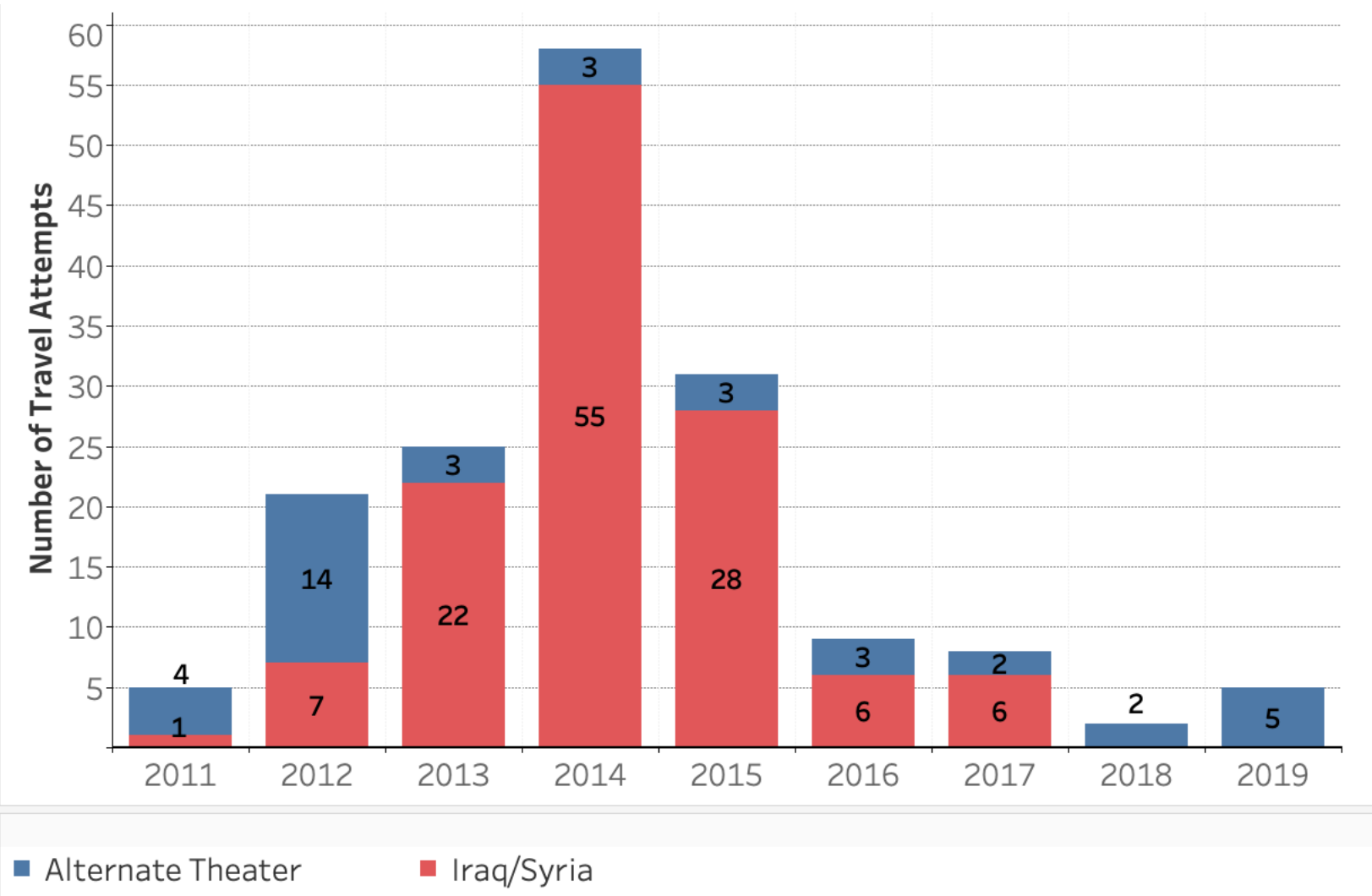




\section{Travel Attempts to Alternate Conflict Theaters (2011-2019)}

Of the 39 attempts by 36 individuals to travel to alternate theaters, 13 attempts were to Af-Pak, ten to Somalia, six to Yemen, four to Libya, three to Egypt, two to Mali, and one to Nigeria. One of the observed secondary attempts is recorded from former New York resident Marcos Alonso Zea, who attempted twice to travel to
Yemen. The second repeated attempt is from former Minnesota resident Tnuza Jamal Hassan, who attempted to join alShabaab after failing to join AQ in Af-Pak. Finally, former Ohio resident Naser Almadaoji attempted to travel to the Af-Pak region after he failed to enter the Sinai Peninsula.

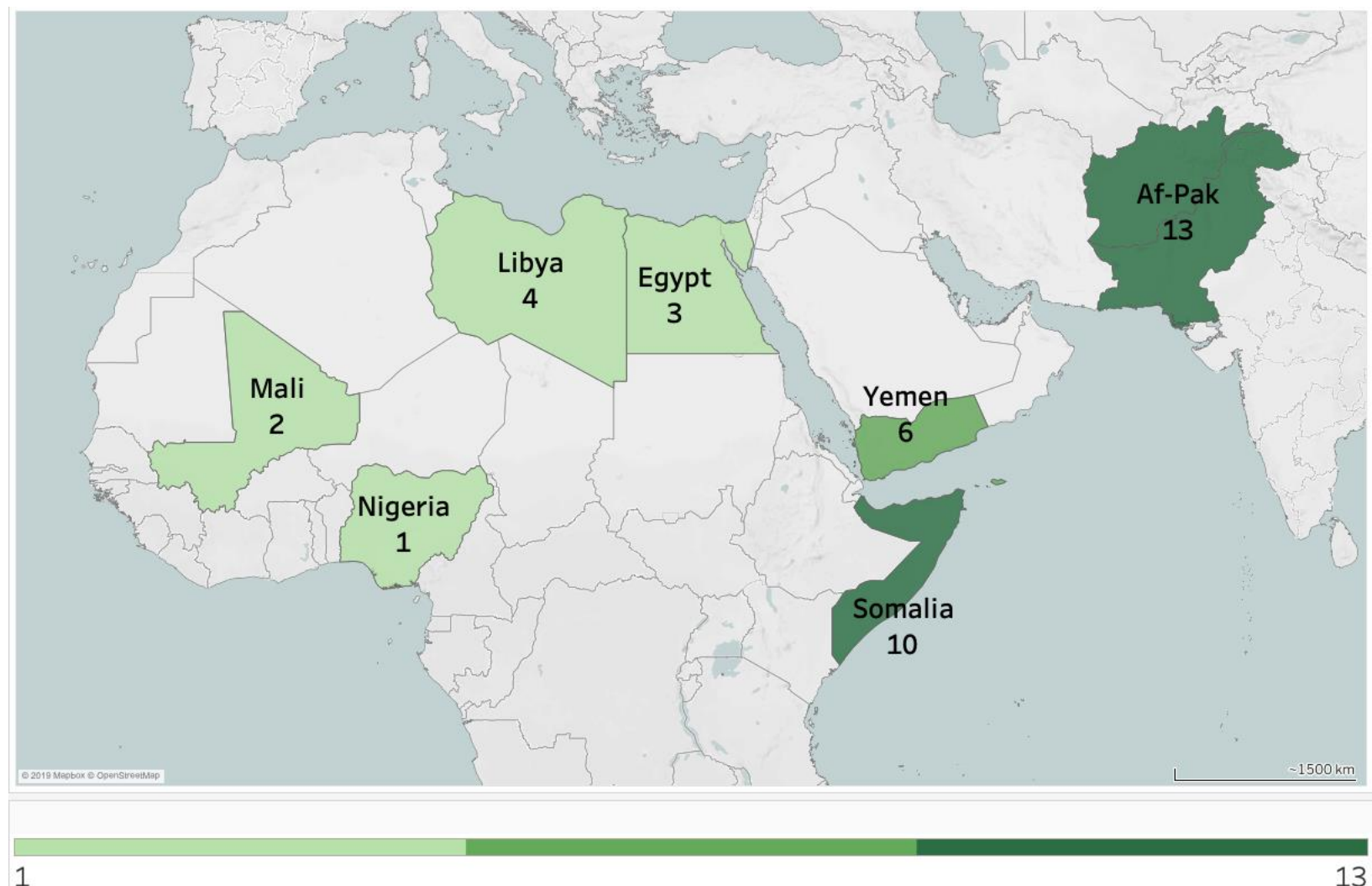




\section{Number of Travel Attempts by Group Affiliation Over Time (2011-2019)}

Between 2011 and 2014, most travelers to alternate theaters attempted to join alQaeda's affiliates al-Qaeda in the Arabian Peninsula (AQAP) in Yemen, al-Shabaab in Somalia, or al-Qaeda core in the Af-Pak region (79\%). Eight individuals attempted to join al-Shabaab, five attempted to join AQAP, and six attempted to join al-Qaeda in Af-Pak. During this time period, two individuals attempted to join an unspecified group in Mali in 2012, one individual attempted to join an unspecified group in Pakistan in 2011, one individual joined Jaish-e-Mohammed (JeM) in Af-Pak in 2014, and one individual attempted to join the Islamic Jihad Union (IJU) in Af-Pak in 2012. ${ }^{\mathrm{xi}}$

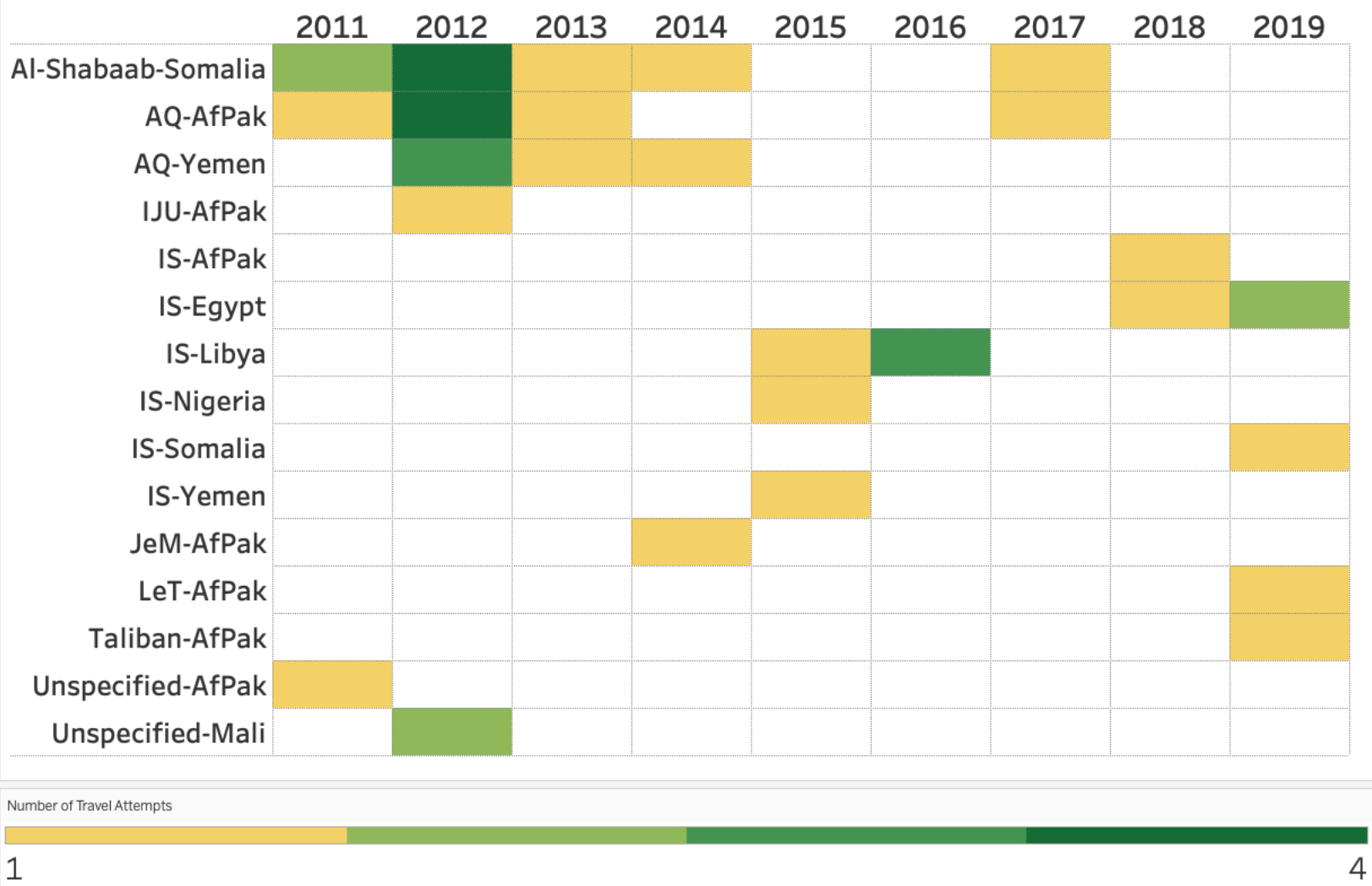

After 2014, the authors recorded only four attempts to join AQ or AQ-aligned groups. One traveler attempted to join al-Shabaab in 2017, one attempted to join AQ in Af-Pak in 2017, one attempted to join the Taliban in 2019, and one attempted to join LeT in 2019. From 2015, the number of travelers to
AQ affiliates was eclipsed by IS affiliates. The study found 11 known attempts to join IS affiliates in Nigeria (one), Somalia (one), the Sinai Peninsula (three), Libya (four), Yemen (one), and Afghanistan (one), accounting for $73 \%$ of all travel attempts since the declaration of the caliphate. 


\section{Ages of Travelers to Destinations Outside Syria/Iraq (2011-2019)}

The average age of individuals who attempted to travel or successfully traveled abroad to join jihadist organizations in Af-Pak, Libya, Mali, Nigeria, the Sinai Peninsula, Somalia, and Yemen was 23.5 years old at the time of travel or attempted travel. The average age of these individuals is slightly younger than the average age of individuals who traveled or attempted to travel to Syria and Iraq (26.6 years old).
The youngest American travelers were Akram Musleh, Justin Kaliebe, Tnuza Hassan, and Shelton Thomas Bell, all 18 years old, who attempted to travel to Libya, Yemen, Af-Pak and Somalia, and Yemen, respectively. The oldest in the sample were Mohamed Rafik Naji (36), who traveled to Yemen in 2015, and Jamshid Muhtorov (also 36), who attempted to travel to Pakistan in 2012.

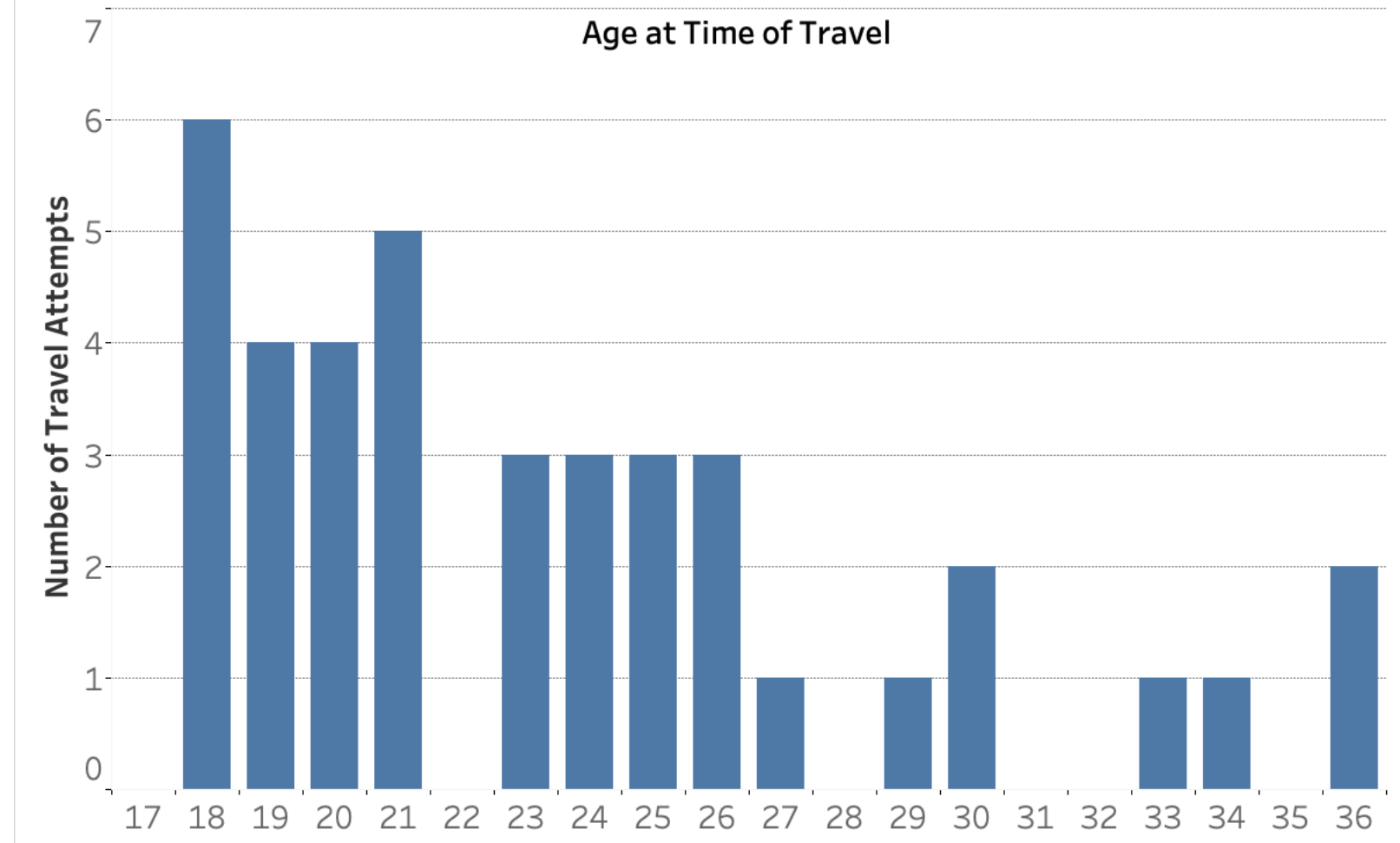




\section{Average Sentencing Length, Successful vs. Unsuccessful Travel (2011-2019)}

Of the 36 individuals in this dataset, ten successfully traveled outside of the United States in their attempt to join jihadist groups not located in Syria and Iraq. 26 individuals were unsuccessful in their attempts. Of the ten successful travelers, four were sentenced in American courts after returning, two are awaiting sentencing, and four remain at large abroad. Of the 26 unsuccessful individuals, 18 were sentenced in American courts and eight are awaiting sentencing. In general, the sentencing lengths vary significantly between individuals who successfully traveled abroad and those who did not; individuals who successfully traveled received sentences on average of almost 90 months more than individuals who were unsuccessful.

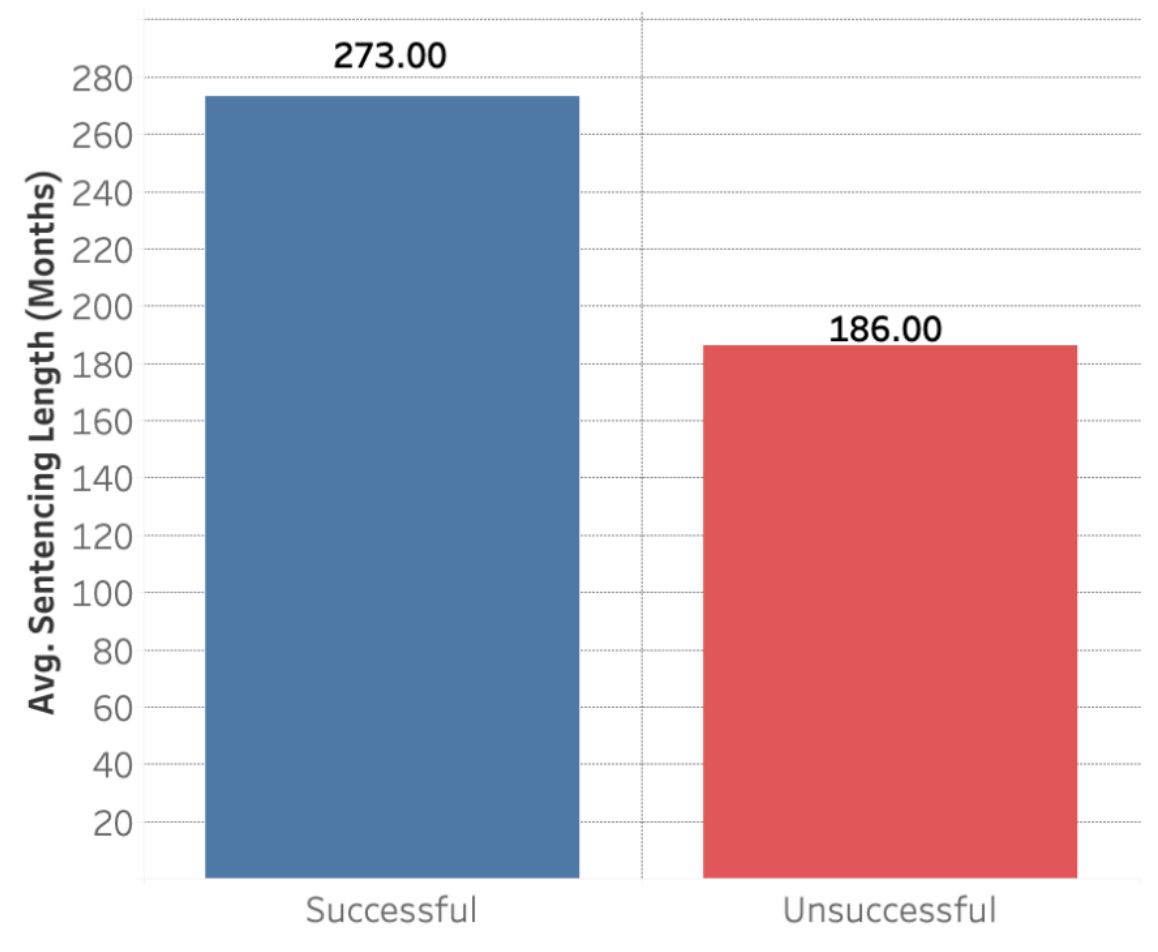




\section{Conclusion}

Prior to the outbreak of the recent conflict in Syria and Iraq and the 2014 declaration of the caliphate by the Islamic State, a substantial majority of American jihadist travelers attempted to join al-Qaeda and its affiliates in a variety of global hotspots. From 2013 onward, the Islamic State in Iraq and Syria drew outsized proportions of American recruits during the caliphate and immediate postcaliphate time period. The mobilization was unprecedented because of the historical significance and international attention paid to the Syrian civil war, the scale and structure of the organization's proto-state, and the initial ease with which individuals traveled from the United States to Syria through Turkey.

Today, although the "postcaliphate" era is in its nascent stages, this research signals that a next possible wave of travelers is feasible, albeit on a smaller scale. Jihadist mobilizations are cyclical, and until a group is able to seize territory, consolidate power, and embark on a sophisticated global messaging strategy similar to that of the Islamic State in Syria and Iraq, the U.S. is unlikely to see an equivalent mobilization of American travelers similar to the caliphate period. Nevertheless, it is difficult to assess the implications of how established and recentlypledged Islamic State affiliates might influence jihadist sympathizers in the mid- to long- term. It is possible that in countries where the Islamic State has a local affiliate, its global branding efforts will surpass al-Qaeda or any other militant organization in drawing American recruits, if any decide to travel at all. Meanwhile, as barriers impeding potential travelers continue to rise, it is likely that supporters will continue turning their focus inward to attacking the homeland.

With so few existing and available cases, it is difficult to develop concrete predictions for American travelers in the rapidly-shifting global jihadist movement. As alQaeda and the Islamic State compete for primacy through internationally-focused

propaganda, global operations, and mobilization of local support, the future of American foreign fighters is unclear. It is not entirely unlikely that this is the beginning of a new, albeit smaller, wave of attempted "pioneer" travelers-individuals who arrive early, build connections in jihadist networks, and contact supporters in the U.S. to encourage them to provide support or join their organizations. xii However, as the conflict dynamics in countries from Nigeria to Afghanistan continue to shift, predicting where Americans will travel in the future remains, for now, a complex but necessary venture for those tasked with anticipating, preventing, and interdicting the next mobilization wave. 


\section{References}

${ }^{i}$ Clapper, James R. (2016), “Senate Select Committee on Intelligence-IC's Worldwide Threat Assessment Opening Statement," Office of the Director of National Intelligence.

https://www.dni.gov/files/documents/2016-02-09SSCI_open threat hearing transcript.pdf

Cook, Joana and Gina Vale (2018), "From Daesh to 'Diaspora': Tracing the Women and Minors of Islamic State," International Centre for the Study of Radicalisation. https://icsr.info/wp-

content/uploads/2018/07/ICSR-Report-From-Daesh-to-\%E2\%80\%98Diaspora\%E2\%80\%99-Tracing-

the-Women-and-Minors-of-Islamic-State.pdf

ii Garamone, Jim (2017), "Dunford: Chiefs of Defense Counter-ISIS Meeting 'Historic." U.S. Department of Defense. https://dod.defense.gov/News/Article/Article/1352920/dunford-chiefs-of-defense-counterisis-meeting-historic/.

iii Meleagrou-Hitchens, Alexander, Seamus Hughes, and Bennett Clifford (2018), "The Travelers: American Jihadists in Syria and Iraq," Program on Extremism.

https://extremism.gwu.edu/sites/g/files/zaxdzs2191/f/TravelersAmericanJihadistsinSyriaandIraq.pdf

iv Witte, Griff, Sudarsan Raghavan, and James McAuley (2016), "Flow of Foreign Fighters Plummets as Islamic State Loses Its Edge," Washington Post. https://www.washingtonpost.com/world/europe/flowof-foreign-fighters-plummets-as-isis-loses-its-edge/2016/o9/og/ed3eodda-751b-11e6-978149e591781754_story.html.

v Meleagrou-Hitchens, Alexander, Seamus Hughes, and Bennett Clifford (2018), "The Travelers: American Jihadists in Syria and Iraq," Program on Extremism.

https://extremism.gwu.edu/sites/g/files/zaxdzs2191/f/TravelersAmericanJihadistsinSyriaandIraq.pdf

vi Margolin, Devorah (2019), “The Changing Roles of Women in Violent Islamist Groups," Program on Extremism.

https://extremism.gwu.edu/sites/g/files/zaxdzs2191/f/The\%20Changing\%2oRoles\%20of\%20Women\%2 oin\%20Violent\%20Islamist\%20Groups.pdf

vii Meleagrou-Hitchens, Alexander, Seamus Hughes, and Bennett Clifford (2018), "The Travelers: American Jihadists in Syria and Iraq." Program on Extremism.

https://extremism.gwu.edu/sites/g/files/zaxdzs2191/f/TravelersAmericanJihadistsinSyriaandIraq.pdf

Gilkes, Sarah (2016), "Not Just the Caliphate: Non-Islamic State-Related Jihadist Terrorism in America," Program on Extremism.

https://extremism.gwu.edu/sites/g/files/zaxdzs2191/f/downloads/Not\%20Just\%20The\%20Caliphate.pd $\underline{f}$

viii In at least seven cases, the authors found individuals who were identified as Americans in open source reporting. However, absent a connection to a legal name, these cases could not be included in the sample.

ix General Intelligence and Security Service (2017), "Jihadist women, a threat not to be underestimated." Ministry of the Interior and Kingdom Relations, Kingdom of the Netherlands. 
https://english.aivd.nl/publications/ publications/2017/12/14/publication-jihadist-women-a- threat-notto-be-underestimated.

x Marcos Alonso Zea, who attempted to travel twice in 2012 to Yemen to join AQAP, was prevented from boarding his connecting flight in London during his first travel attempt. After he returned home, he made a secondary attempt later that year. Tnuza Jamal Hassan attempted to join AQ in Af-Pak in 2017, but was stopped in the Middle East. Later that year, she tried to join al-Shabaab in Somalia, but was stopped in the U.S. for using her sister's identification documents rather than her own. Finally, Naser Almadaoji attempted to travel once in 2018 to the Sinai Peninsula to join the Islamic State's local affiliate, but was robbed by his fixer and forced to return to the U.S. Later that year, he attempted to join the Islamic State Khorasan, IS' affiliate in the Af-Pak region.

Press Release (2015), "Long Island Man Sentenced to 25 Years in Prison for Attempting to Join Al-Qaeda in the Arabian Peninsula," Department of Justice. https://www.justice.gov/usao-edny/pr/long-islandman-sentenced-25-years-prison-attempting-join-al-qaeda-arabian-peninsula; USA vs. Tnuza Jamal Hassan, Memorandum in Support of Detention (February 2018); USA vs. Naser Almadaoji, Criminal Complaint (October 2018).

xi Notably, these two groups have a history of either providing operational assistance or of maintaining close ties and allying with al-Qaeda.

xii Meleagrou-Hitchens, Alexander, Seamus Hughes, and Bennett Clifford (2018), "The Travelers: American Jihadists in Syria and Iraq." Program on Extremism. https://extremism.gwu.edu/sites/g/files/zaxdzs2191/f/TravelersAmericanJihadistsinSyriaandIraq.pdf

xiii Berger, J. M. (2011). Jihad Joe: Americans Who Go to War in the Name of Islam. Washington, DC: Potomac Books, Inc.

xiv Meleagrou-Hitchens, Alexander, Seamus Hughes, and Bennett Clifford (2018), "The Travelers: American Jihadists in Syria and Iraq." Program on Extremism.

https://extremism.gwu.edu/sites/g/files/zaxdzs2191/f/TravelersAmericanJihadistsinSyriaandIraq.pdf

xv Hafez, Mohammed (2009), "Jihad after Iraq: Lessons from the Arab Afghans". Studies in Conflict \& Terrorism, 32 (2): 73-94. https://doi.org/10.1080/10576100802639600.; Berger, J. M. (2011). Jihad Joe: Americans Who Go to War in the Name of Islam. Washington, DC: Potomac Books, Inc.

xvi Jenkins, Brian (2014), "When Jihadis Come Marching Home: The Terrorist Threat Posed by Westerners Returning from Syria and Iraq." RAND Corporation.

https://www.rand.org/pubs/perspectives/PE130-1.html

xvii Berger, J. M. (2011). Jihad Joe: Americans Who Go to War in the Name of Islam. Washington, DC: Potomac Books, Inc.

xviii Ibid.

xix Jenkins, Brian (2014), "When Jihadis Come Marching Home: The Terrorist Threat Posed by Westerners Returning from Syria and Iraq.” RAND Corporation. https://www.rand.org/pubs/perspectives/PE130-1.html 
xx Richardson, Matthew W. (2012), "Al-Shabaab's American Recruits: A Comparative Analysis of Two Radicalization Pathways," ETD Collection for University of Texas at El Paso, https://digitalcommons.utep.edu/dissertations/AAI1512635/.

xxi U.S. Department of Homeland Security Countering Violent Extremism Task Force (2017), "Reference Aid: U.S. Foreign Fighters," Department of Homeland Security

https://www.dhs.gov/sites/default/files/publications/Foreign\%20Fighters_CVE\%20Task\%20Force_Fin al.pdf.

xxii University of Southern California's National Center of Excellence for Risk and Economic Analysis of Terrorism Events (2015), "Foreign Fighters: Terrorist Recruitment and Countering Violent Extremism (CVE) Programs in Minneapolis-St. Paul.” USC CREATE. http://securitydebrief.com/wpcontent/uploads/2015/O4/Foreign-Fighters-Terrorist-Recruitment-and-CVE-in-Minneapolis-StPaul.pdf.

xxiii Meleagrou-Hitchens et al. (2012), "Lights, Camera, Jihad: Al-Shabaab’s Western Media Strategy," International Centre for the Study of Radicalisation and Political Violence. https://icsr.info/wpcontent/uploads/2012/11/ICSR-Report-Lights-Camera-Jihad-al-Shabaab\%E2\%80\%99s-Western-MediaStrategy.pdf

xxiv Jenkins, Brian (2014), "When Jihadis Come Marching Home: The Terrorist Threat Posed by Westerners Returning from Syria and Iraq." RAND Corporation. https://www.rand.org/pubs/perspectives/PE130-1.html

xxv Mazzetti, Schmitt, and Worth (2011), “Two-Year Manhunt Led to Killing of Awlaki in Yemen,” New York Times. https://www.nytimes.com/2011/10/01/world/middleeast/anwar-al-awlaki-is-killed-inyemen.html 


\title{
Appendix 1: List of Travelers
}

\author{
ABUKHDAIR, Mohammad Abdul Rahman \\ ALMADAOJI, Naser \\ ALRAYANNI, Bilal \\ AUGUSTINE, Bernard \\ BAXAM, Craig \\ BELL, Shelton Thomas \\ DANIELS, Aaron T. \\ DELEON, Ralph \\ EDMONDS, Hasan Rasheed \\ ENCARNACION, Jesus Wilfredo \\ FARAH, Omar Ali \\ FURREH, Mahdi \\ HUSSEIN, Abdi Yemani \\ GOJALI, Arifeen David \\ HASBAJRAMI, Agron \\ HASSAN, Tnuza Jamal \\ HOSSAIN, Delowar Mohammed \\ JALLOH, Mohamed Bailor \\ JONES, Maalik Alim \\ KABIR, Sohiel Omar \\ KALIEBE, Justin \\ KHAN, Rahatul Ashikin \\ MOHAMED, Ahmed Mahad \\ MOHAMED, Liban Haji \\ MUHTAROV, Jamshid \\ MUSE, Muse Abdikadir \\ MUSLEH, Akram I. \\ NAJI, Mohamed Rafik \\ NGUYEN, Sinh Vinh Ngo \\ OSMAN, Mohamed \\ OSMAN, Mohamed Guled \\ QAZI, Raees Alam \\ ULHASSAN, Waqar \\ VIDRIALES, Miguel Alejandro Santana \\ WILSON, Randy "Rasheed" \\ ZEA, Marcos Alonso
}




\section{Appendix 2: An Abridged History of Prior American Travelers Beyond Syria and Iraq}

It is estimated that since 1979, there are hundreds of documented cases of individuals from the United States traveling abroad to join jihadist movements in the Af-Pak region, Bosnia, Yemen, Somalia, and other conflict theaters, with the number of travelers ebbing and flowing over time. xiii The following sections provide a very brief historical perspective of past American foreign fighter flows.

\section{Af-Pak Region}

The Afghan-Soviet conflict sparked an initial wave of American travelers in the early 1980s. At the time, recruiters used non-governmental organizations as fronts to coax would-be sympathizers across the United States to their cause, ${ }^{\text {xiv }}$ building up the allure of joining the mujahideen "freedom fighters" in ousting one of the major world powers of the $20^{\text {th }}$ century from Afghanistan. After the Soviet Army withdrew by 1989, the remaining foreign fighters either stayed in Afghanistan, returned home, or moved on to other conflict zones. ${ }^{x v}$ The events of 9/11 and subsequent American invasion of Afghanistan, however, opened up the opportunity for jihadist organizations to reignite their fight against a new external enemy-the United States. That strategic reframing served as a major pull factor for a new wave of American foreign fighters to Afghanistan in the mid-to-late 2000s. The total number of known travelers was relatively small; one report by Brian Jenkins accounted for 21 Americans who joined jihadist groups operating in the region between Afghanistan and Pakistan (Af-Pak) from 2001-2011. ${ }^{\text {xvi }}$ The majority of these individuals sought to join the major organizations fighting American and allied forces, including the Taliban, Al-Qaeda, and Lashkar-e-Taiba. Today, these groups continue to endure and adapt, though they now compete with the Islamic State's local affiliatethe Islamic State Khorasan (ISK) - which declared allegiance to al-Baghdadi in January 2015.

\section{Bosnia}

The start of the Bosnian War triggered more American travelers in the early 1990s. ${ }^{\text {xvii }}$ Some had experience in other conflicts, including training with the mujahideen in Afghanistan, fighting experience from the Vietnam and Gulf Wars, and some Special Forces training. This time, recruiters in the U.S. used the mass rape of Bosnian Muslim women and ethnic cleansing of Bosnian Muslims to mobilize American support. These recruits were organized into two groups of travelers and sent to train and assist jihadists in Bosnia. Later recruits who did not have prior fighting experience were sent to a training camp in rural Pennsylvania, which was ultimately converted to focus on plotting attacks at home. ${ }^{\text {xvii }}$ With the close of the Bosnian War, the surviving foreign fighters returned home or left for other conflict zones.

\section{Somalia}

The emergence of al-Shabaab in Somalia in 2006 drew over 30 Americans to the group between 2007 and 2011. ${ }^{\text {xix }}$ The first group of travelers, primarily Somali-Americans from Minneapolis, Minnesota, left the U.S. to join the group in 2007 following the deployment of Ethiopian troops 
to Somalia. A range of factors from social bonds to political grievances to nationalism and jihadist ideology and other drivers are believed to have motivated these individuals to travel and join the group.xx Many who traveled to Somalia chose to stay. Despite the early appeal of alShabaab, the number of attempted and successful travelers has fallen since 2012 after the group pledged allegiance to al-Qaeda.xi While some observers contributed the decline in Americans traveling to Somalia partially to negative perceptions regarding the atrocities committed and false narratives espoused by al-Shabaab, xxii it is more likely that an internal purge and growing mistrust of foreign fighters beginning in 2012 contributed to the decline. xiii That decline was also amplified by the rise of the Islamic State, which cannibalized on potential recruits and convinced them to travel to Syria and Iraq instead.

\section{Yemen}

Al-Qaeda's branch in Yemen, al-Qaeda in the Arabian Peninsula (AQAP) drew at least seven known cases of American jihadist travelers between 2001 and 2011. ${ }^{x x i v}$ AQAP's appeal to American recruits received a significant boost after well-known ideologue Anwar al-Awlaki, a New Mexico-born Yemeni-American preacher, joined the group and served as a senior recruiter and propagandist. Al-Awlaki was joined by Samir Khan, who left North Carolina to join the terrorist organization in 2009. The pair reportedly co-founded AQAP's Inspire magazine, an English-language publication aimed at garnering support from British and American audiences. Both men were killed in a U.S. drone strike in September 2011. ${ }^{\mathrm{xxv}}$ 